\title{
Editorial
}

\section{Novos degraus para elevação da pesquisa científica em Escola Austríaca}

\author{
Adriano Paranaiba*
}

Certa vez, Martin Luther King disse que não é necessário que você veja toda a escada, apenas que dê o primeiro passo. Acredito que, em 2013, no lançamento do primeiro número da MISES: Revista Interdisciplinar de Filosofia, Direito e Economia, o corpo editorial não tinha percepção do alcance que aquele primeiro passo teria sete anos depois. Contudo, a crença no potencial desta importante corrente do pensamento econômico, trazia esperança aos pioneiros deste importante projeto.

No primeiro editorial deste periódico, o professor Ubiratan Iorio, diretor acadêmico do Instituto Mises Brasil, apresentava o primeiro número com "grande esperança intelectual”, e sonhava que a revista pudesse ser referência "não apenas no que se refere a seu pioneirismo em termos de ser a primeira especializada na Escola Austríaca em língua portuguesa, mas principalmente, como veículo acadêmico interdisciplinar de altíssimo nível, como um espaço permanente aberto ao debate de ideias".

E assim, a revista foi conquistando o público brasileiro, apresentando artigos consagrados traduzidos em português, tornando possível o acesso à literatura desta escola, bem como incentivando pesquisadores a submeterem seus artigos, sempre acreditando no potencial deste veículo acadêmico. É verdade que, naqueles tempos, ainda era possível contar nos dedos da mão quantos pesquisadores dedicados à Escola Austríaca existiam no Brasil. Contudo, era preciso fomentar novas pesquisas e dar visibilidade a esses pesquisadores. Para além disso, esse periódico acadêmico assumiu um papel importante na formação de uma nova geração de pesquisadores, mestres e doutores no Brasil, norteando trabalhos que envolviam contribuições acadêmicas de Menger, Mises e Hayek.

\footnotetext{
* Adriano Paranaiba é economista. Doutor em Transportes pela Universidade de Brasília (UNB). Editor-chefe da MISES: Revista Interdisciplinar de Filosofia, Direito e Economia, bem como da sua versão on-line MISES: Interdiscplinary Journal of Philososphy, Law and Economics. E-mail: paranaiba@mises.org.br
} 
A cada degrau conquistado, novos desafios foram surgindo. Até que, no final de 2017, um novo grande passo foi dado: a produção e publicação on-line. Não tratava-se apenas de disponibilizar na internet o conteúdo produzido, mas sim de modernizar todo o processo editorial, implantando as melhores práticas editoriais. Com essa edição, a segunda de 2019, o periódico soma mais de trezentos artigos, resenhas e traduções publicados.

É evidente que nem todas as passadas nos levaram a degraus elevados. Algumas vezes, degraus insólitos de tormentos precisam ser enfrentados. Um dos mais brilhantes pesquisadores nos deixou na jornada desta escada, em 2019: Gabriel Oliva, que faria 30 anos e fazia Doutorado em Economia na Duke. Sua partida fora repentina, só não tão impactante como foi a sua salutar presença no tempo em que esteve entre nós. Nas palavras do professor Fábio Barbieri, Gabriel "além de brilhante estudante nas matérias regulares dos cursos, era um intelectual e não um mero técnico ou especialista. Ele era um daqueles 'nerds' cada vez mais raros de se encontrar, que devoravam tudo o que era escrito sobre os assuntos que estudava, mas sem nunca se comportar com a arrogância típica dos economistas".

Desta forma, a edição do II Concurso de Artigos da VI Conferência de Escola Austríaca, do Instituto Mises Brasil, homenageia de modo mais do que justo Gabriel Oliva, instituindo seu nome ao Prêmio deste Concurso. Essa edição começa com a publicação dos artigos finalistas.

Marcelo Lourenço Filho, com o artigo Os austríacos e o método: da crítica ao positivismo ao resgate da tradição clássica, conquistou o primeiro lugar, em uma decisão acirrada. A disputa foi travada com João Pedro Bastos que, com o artigo Economics Against Tyranny: A Reassessment of the Liberal Order of Mises and Hayek, alcançou o segundo mais alto lugar do pleito. José Hamilton dos Santos Batista ficou em terceiro lugar, trazendo Os Quatro Problemas das Instituições Econômicas e o Debate do Cálculo Econômico Socialista.

Mesmo que o intuito do Concurso Gabriel Oliva fosse premiar apenas os três primeiros colocados, a menção honrosa foi concedida para João Fernando Rossi Rossi Mazzoni, com seu artigo Falhas de mercado no setor aeroportuário e contraposição da visão neoclássica com a escola austríaca e a escola de public choice. É importante destacar que os finalistas do concurso, após uma fase classificatória, apresentaram seus artigos e foram arguidos por uma banca formada pelos professores Vladimir Fernandes Maciel e Mariana Piaia Abreu. Aproveitamos a oportunidade para, em nome dos dois professores, agradecermos aos demais que auxiliaram nessa árdua tarefa de avaliar as centenas de artigos que foram submetidos ao concurso. Sabemos que, ao contrário do tempo, que era em demasia escasso, o empenho foi colossal e efetivo.

Dando seguimento à seção de artigos de pesquisa, o artigo An Essay on Adaptive Development, de Gabriel Braga Filartiga, apresenta a eficiência adaptativa como produto de um processo evolutivo em que prevalecem certos tipos de aprendizagem que, ou condenam as sociedades a ciclos viciosos de subdesenvolvimento, ou pavimentam seu caminho para a prosperidade.

Na sequência, Samuel Fernandes Lucena Vaz-Curado e Antony Peter Mueller nos brindam com um artigo que aborda uma análise de uma nova teoria econômica que vem ganhando espaço na discussão, especialmente em países desenvolvidos, como os Estados Unidos. O trabalho A Teoria Monetária Moderna: Uma Avaliação de suas Premissas e suas Consequências Políticas é um artigo cirúrgico em seus achados teóricos e que fundamentam críticas amplamente pertinentes. André Borges Uliano, em A Doutrina Social da Igreja Católica e a teoria do Livre Mercado: pontos 
de convergência, analisa a existência de compatibilidade com os conceitos de Livre Mercado e a Doutrina Social da Igreja Católica.

Encerrando a seção, As teorias da justiça de Hayek e Rawls: divergências e convergências além da mera terminologia, de Matheus de Quadros, traz uma reflexão destes grandes expoentes do liberalismo.

A seção Ensaios \& Insights é composta por dois artigos. A História da Moeda - Uma proposta de união entre Teoria Econômica e Etnografia, dos autores Marcel Pereira Bernardo, Rodrigo Braian Nori e Luan Vinicius Bernardelli, que faz um rico estudo bibliográfico sobre a moeda. E o empreito desenvolvido por Gabriel Estruzani Queiróz de Melo, que fecha a seção com $A$ Influência da Filosofia Escolástica na Formação do Pensamento Econômico, rememorando os elos que a Escola Austríaca possui com a Escola de Salamanca.

Mantendo a tradição deste periódico, apresentamos a tradução de um importante artigo de Thomas J. DiLorenzo sobre regulação que, até então, não possuía versão em língua portuguesa. Logo, o constructo As origens do movimento antitruste: a perspectiva de um grupo de interesse é colocado nesta edição sob precisa tradução de João Felipe Rodrigues Lanza.

Concluindo essa edição, dois livros foram resenhados. Free Private Cities: Fazendo Governos Competirem por Você, de autoria de Titus Gebel, e cuja resenha foi feita por Francisco Litvay, uma contribuição lusitana. E por fim, fui surpreendido pela editora de textos deste periódico, Priscilla Guerra Guimarães Bernardes, que fez a resenha do livro de minha autoria e do professor Eliezé Bulhões, Transportar é Preciso: uma proposta liberal.

O biólogo britânico, Thomas Huxley, nos relata que "o degrau de uma escada não serve simplesmente para que alguém permaneça em cima dele, destina-se a sustentar o pé de um homem pelo tempo suficiente para que ele coloque o outro um pouco mais alto". Que essa definição nos sirva de inspiração em nossa caminhada. E que assim, possamos, a cada edição, sustentar os novos passos sempre à frente e vertiginosamente. Sobretudo, que cada nova revista seja ainda mais suporte, mais esteio e terra cada vez mais firme para a pesquisa da Escola Austríaca no Brasil.

Uma boa leitura a todos. 